\title{
MATHEMATICAL MODEL OF BLOOD COLLECTION ROUTING PROBLEM
}

\author{
Nur Mayke Eka Normasari ${ }^{*}$, Nabilah Muallifah \\ Departemen Teknik Mesin dan Industri Fakultas Teknik, Universitas Gadjah Mada \\ Jl. Grafika No. 2 Yogyakarta 55281 Indonesia \\ mayke@ugm.ac.id
}

\begin{abstract}
The scarcity of blood that is still happening today is the result of a combination of high blood needs and the difficulty of recruiting and maintaining donors. There is no research discover the substitute that can replace the role of blood, therefore the only source is from donations or blood donors. Approximately $80 \%$ of total blood donations collected by American Red Cross are come from blood drive events. Because blood has 6-hour spoilage time, donated blood at various donation locations must be collected and sent to a blood center for processing in less than 6 hours. This research study the Maximum Blood Collection Routing Problem (MBCRP). This problem is the extension of Vehicle Routing Problem with Time-Window (VRPTW) by considering the spoilage time limitation in blood. A mathematical model with objective to maximize total blood collection is built to cope with this problem. The mathematical model will be tested for verification and validation. The model is written in a computer programming language using AMPL software and is solved using the CPLEX solver. Furthermore, the results of verification and validation tests will be evaluated to see the applicability of the model.
\end{abstract}

Keyword: Maximum Blood Collection Routing Problem, spoilage time, blood center VRPTW, CPLEX

Abstrak

Kelangkaan darah yang saat ini masih terjadi merupakan hasil kombinasi dari tingginya kebutuhan darah serta sulitnya merekrut dan mempertahankan pendonor. Sampai saat ini belum ada penemuan yang dapat menggantikan peran darah sehingga satu-satunya sumber adalah dari donasi atau donor darah. Sekitar $80 \%$ dari total donasi darah yang ditangani oleh American Red Cross merupakan donasi yang dilakukan pada event donor darah atau blood drive. Karena darah memiliki spoilage time selama 6 jam, maka darah hasil donasi di berbagai lokasi donasi harus dikumpulkan dan dikirimkan ke blood center untuk diproses dalam waktu kurang dari 6 jam.

Penelitian ini mengkaji tentang Maximum Blood Collection Routing Problem (MBCRP). Permasalahan pengumpulan darah ini merupakan pengembangan dari permasalahan pemilihan rute optimal dengan time-window yang dikenal dengan istilah Vehicle Routing Problem with Time-Window (VRPTW) dengan memertimbangkan adanya batasan spoilage time pada darah. Sebuah model matematis dengan fungsi tujuan untuk memaksimalkan total suplai darah dibangun untuk menyelesaikan permasalahan tersebut.

Model matematis yang dibangun akan dilakukan uji verifikasi dan validasi. Model tersebut dituliskan dalam bahasa pemrograman komputer dengan menggunakan perangkat lunak $A M P L$ dan diselesaikan dengan menggunakan solver CPLEX. Selanjutnya hasil uji verifikasi dan validasi akan dievaluasi untuk melihat kemampuan model untuk digunakan. 
Kata Kunci: Maximum Blood Collection Routing Problem, spoilage time, blood center VRPTW, CPLEX

\section{Pengantar}

Darah merupakan cairan dalam tubuh manusia yang berperan penting dalam proses metabolisme tubuh. Hal tersebut dikarenakan darah memiliki beberapa fungsi, di antaranya adalah sebagai alat pendistribusi nutrisi dan oksigen ke seluruh tubuh serta menghasilkan antibody [1]. Hal tersebut menyebabkan darah sangat dibutuhkan dalam beberapa pengobatan termasuk transplantasi organ, kanker, anemia, dan operasi-operasi besar seperti bedah jantung [2]. Menurut Davey [3], kebutuhan akan darah diprediksi akan semakin meningkat. Hal tersebut diakibatkan oleh peningkatan angka harapan hidup manusia dan perkembangan di bidang medis khususnya pada pengobatan-pengobatan yang membutuhkan transfusi darah. Perbandingan kebutuhan ideal dan ketersediaan darah di beberapa Provinsi di Indonesia dapat dilihat pada Tabel 1. Jumlah ideal kebutuhan darah adalah sebesar 2,5\% dari jumlah penduduk [4]. Sehingga dapat diketahui bahwa Indonesia membutuhkan setidaknya sekitar 5,1 juta kantong per tahun. Akan tetapi berdasarkan data statistik yang dikeluarkan oleh Pusat Data dan Informasi Kementerian Kesehatan RI [5] pada Tabel 1, ketersediaan darah di Indonesia baru sebanyak 4,1 juta kantong per tahun. Akibatnya, banyak rumah sakit mengalami kesulitan dalam memenuhi kebutuhan transfusi darah.

Menurut Belien dan Force [6], kekurangan persediaan darah dapat menimbulkan kerugian pada masyarakat karena dapat meningkatkan angka kematian. Fenomena kematian yang disebabkan oleh kekurangan darah tersebut masih terjadi di banyak negara. Di Indonesia sendiri, sebesar 31\% kematian ibu melahirkan disebabkan oleh keterbatasan darah ketika terjadi pendarahan [7].

Fenomena kelangkaan darah merupakan hasil kombinasi dari tingginya angka kebutuhan darah serta sulitnya merekrut dan mempertahankan pendonor [8]. Sampai saat ini belum ada penemuan yang dapat menggantikan peran darah sehingga satu-satunya sumber adalah dari donasi atau donor darah [9]. Menurut American Red Cross [10], 80\% dari total darah yang ditangani oleh American Red Cross merupakan donasi yang dilakukan pada event donor darah. Oleh karena itu dibutuhkan strategi untuk memaksimalkan darah yang dapat dikumpulkan dari berbagai event donor darah sebagai salah satu upaya untuk mencegah terjadinya fenomena kelangkaan darah.

Berdasarkan regulasi yang dikeluarkan oleh American Association of Blood Banks (AABB) dan Food and Drug Administration (FDA), darah segar direkomendasikan untuk diproses dan dipisahkan komponen-komponennya dalam waktu 6 jam hingga tidak lebih dari 18 jam setelah diambil dari tubuh pendonor [11]. Karena keterbatasan alat serta kebutuhan akan kondisi penyimpanan yang khusus, proses pemisahan komponen-komponen darah hanya dapat dilakukan di pusat pemrosesan yang terdapat di blood center. Oleh karena itu darah hasil donasi di berbagai lokasi donasi harus dikumpulkan dan dikirimkan ke blood center untuk diproses dalam waktu kurang dari 6 jam[12-13].

Menurut National Health Service Blood and Transplant [14] dan ABC Radio Darwin [15], secara umum sistem donor darah diawali dengan pengambilan darah dari pendonor di berbagai lokasi donasi. Darah tersebut kemudian dikumpulkan dan diangkut menggunakan kendaraan yang dilengkapi dengan pengatur suhu sebagai tempat penyimpanan sementara darah menuju pusat pemrosesan yang terletak di blood center. Selajutnya dilakukan pengujian dan analisis terhadap sampel darah apakah darah layak untuk digunakan atau tidak. Setelah dinyatakan lolos, darah kemudian diproses untuk dipisahkan dalam bentuk komponen-komponen darah dan disimpan. Stok darah baru akan dikirim menuju rumah sakit jika terdapat permintaan. 
Tabel 1. Minimal Kebutuhan Darah dan Produksi Darah per Provinsi Tahun 2015 [5]

\begin{tabular}{|c|c|c|c|c|c|}
\hline No & Provinsi & $\begin{array}{c}\text { Jumlah } \\
\text { Penduduk }\end{array}$ & $\begin{array}{c}\text { Minimal } \\
\text { Kebutuhan } \\
\text { Daerah } \\
\text { (2\% dari jumlah } \\
\text { penduduk) }\end{array}$ & $\begin{array}{c}\text { Produksi } \\
\text { Daerah }\end{array}$ & $\begin{array}{c}\text { Presentase } \\
\text { Pemenuhan } \\
\text { Kebutuhan } \\
\text { Darah } \\
(\%)\end{array}$ \\
\hline 1 & Aceh & $5,001,953$ & 100,039 & 68,668 & 68.64 \\
\hline 2 & Sumatera Utara & $13,937,797$ & 278,756 & 102,969 & 36.94 \\
\hline 3 & Sumatera Barat & $5,196,289$ & 103,926 & 87,993 & 84.67 \\
\hline 4 & Riau & $6,334,402$ & 126,888 & 81,914 & 64.56 \\
\hline 5 & Kepulauan Riau & $1,973,043$ & 39,461 & 23,627 & 59.87 \\
\hline 6 & Jambi & $3,402,052$ & 68,041 & 28,018 & 41.18 \\
\hline 7 & Sumatera Selatan & $8,052,315$ & 161,046 & 57,029 & 35.41 \\
\hline 8 & Bengkulu & $1,874,940$ & 37,499 & 14,005 & 37.35 \\
\hline 9 & Lampung & $8,117,268$ & 162,345 & 81,524 & 50.22 \\
\hline 10 & Kep. Bangka Belitung & $1,372,813$ & 27,456 & 21,222 & 77.29 \\
\hline 11 & DKI Jakarta & $10,177,924$ & 203,558 & 588,475 & 289.09 \\
\hline 12 & Jawa Barat & $46,709,569$ & 934,191 & 524,047 & 56.1 \\
\hline 13 & Banten & $11,955,243$ & 239,105 & 144,057 & 60.25 \\
\hline 14 & Jawa Tengah & $33,774,141$ & 675,483 & 652,961 & 96.67 \\
\hline 15 & Yogyakarta & $3,679,176$ & 73,584 & 115,296 & 156.69 \\
\hline 16 & Jawa Timur & $38,847,561$ & 776,951 & 905,576 & 116.56 \\
\hline 17 & Bali & $4,152,833$ & 83,057 & 96,303 & 115.95 \\
\hline 18 & Nusa Tenggara Barat & $4,835,577$ & 96,712 & 14,110 & 14.59 \\
\hline 19 & Nusa Tenggara Timur & $5,120,061$ & 102,401 & 19,131 & 18.68 \\
\hline 20 & Kalimantan Barat & $4,789,574$ & 95,791 & 45,335 & 47.33 \\
\hline 21 & Kalimantan Tengah & $2,495,030$ & 49,901 & 20,440 & 40.96 \\
\hline 22 & Kalimantan Selatan & $3,989,793$ & 79,796 & 64,331 & 80.62 \\
\hline 23 & Kalimantan Timur & $3,426,638$ & 68,533 & 71,594 & 104.47 \\
\hline 24 & Kalimantan Utara & 641,936 & 12,839 & 11,132 & 86.7 \\
\hline 25 & Sulawesi Utara & $2,412,118$ & 48,242 & 41,891 & 86.84 \\
\hline 26 & Sulawesi Tengah & $2,876,689$ & 57,534 & 25,115 & 43.65 \\
\hline 27 & Sulawesi Selatan & $8,520,304$ & 170,406 & 104,721 & 61.45 \\
\hline 28 & Sulawesi Tenggara & $2,499,540$ & 49,991 & 12,939 & 25.88 \\
\hline 29 & Gorontalo & $1,133,237$ & 22,665 & 14,015 & 61.84 \\
\hline 30 & Sulawesi Barat & $1,282,162$ & 25,643 & 7,021 & 27.38 \\
\hline 31 & Maluku & $1,686,469$ & 33,729 & 4,022 & 11.92 \\
\hline 32 & Maluku Utara & $1,162,345$ & 23,247 & 1,380 & 5.94 \\
\hline 33 & Papua Barat & 871,510 & 17,430 & 1,796 & 10.3 \\
\hline 34 & Papua & $3,149,375$ & 62,988 & 19,779 & 31.4 \\
\hline & Total & $255,451,677$ & $5,109,234$ & $4,072,436$ & $79.71^{*}$ \\
\hline
\end{tabular}

*rata-rata 
Menurut Finnish Red Cross Blood Service [16], setiap minggunya blood center mengorganisir setidaknya 20-25 event donor darah di berbagai lokasi di Finlandia. Maka, dalam sehari kendaraan pengangkut darah yang dimiliki oleh blood center harus mengunjungi 3-4 event donor darah untuk mengumpulkan darah hasil donasi dan membawanya kembali ke blood center untuk diproses lebih lanjut. Dalam hal ini, dibutuhkan sebuah strategi untuk menentukan lokasi potensial event donor darah yang harus dikunjungi sekaligus rute pick-up kendaraan agar jumlah darah yang dikumpulkan maksimal dan tidak melewati batasan spoilage time darah.

Penelitian ini membahas tentang pengembangan model matematis untuk menjawab permasalahan Maximum Blood Collection Routing Problem (MBCRP) yaitu pemilihan lokasi event donor darah yang akan dikunjungi oleh kendaraan pengangkut darah beserta penentuan rute pick-up optimalnya. Tujuan utamanya adalah untuk memaksimalkan total suplai darah yang dapat dikumpulkan. Batasan-batasan waktu yang dipertimbangkan pada penelitian ini adalah masa kadaluarsa darah (spoilage time), jam operasional lokasi donasi, serta jam operasional pusat pemrosesan (blood center). Model matematis juga dibangun untuk mengakomodasi keterbatasan jumlah kapasitas kendaraan yang dapat digunakan untuk mengumpulkan suplai darah. Sehingga, dapat diketahui berapa total suplai maksimum yang dapat dikumpulkan dengan menggunakan sumber daya tersedia.

\section{Metodologi Penelitian}

Penelitian ini diawali dengan mengamati mekanisme system pengumpulan darah dengan melakukan observasi pada sistem nyata. Tahap ini dilakukan untuk mengevaluasi cara kerja, parameter dan variabel keputusan dari permasalahan yang diselesaikan. Pada tahap ini juga dilakukan studi literature untuk mengetahui pendekatan penelitian VRP yang relevant pada permasalahan yang akan diselesaikan.

Tahap selanjutnya adalah pembuatan model matematis dengan karakteristik sistem yang telah ditentukan pada tahap sebelumnya. Model matematis dibuat dalam bentuk mixed integer non-linear programming (MINLP) dengan fungsi tujuan untuk memaksimalkan jumlah kantong darah yang dapat dikumpulkan. Model matematis yang dibangun kemudian ditulis dalam bahasa pemrograman komputer dengan bantuan software AMPL dan diselesaikan dengan menggunakan CPLEX solver.

Tahap akhir adalah tahap verifikasi dan validasi. Proses verifikasi dilakukan untuk memastikan bahwa cara kerja serta output program komputer telah sesuai dengan yang diharapkan yaitu sesuai dengan model matematis dan tidak melanggar batasan-batasan yang telah ditentukan sebelumnya. Sedangkan proses validasi dilakukan pada pebelitian ini adalah validasi output. Validasi output dilakukan dengan cara membandingkan hasil dari program komputer dengan hasil perhitungan secara manual. Jika kedua perhitungan memberikan hasil yang identik, maka model dapat dikatakan valid.

\section{Hasil dan Pembahasan}

Pada bagian ini akan disampaikan model matematis yang telah dibangun dan hasil pengujian verifikasi dan validasi dari model yang dibangun.

\subsection{Pembangunan Model Matematis}

Pada penelitian ini, dibangun model matimatis dari system MBCRP. Didalam model yang dibangun, terdapat beberapa lokasi potensial untuk melakukan event donor darah dimana masing-masing lokasi potensial tersebut memiliki estimasi banyaknya kantong darah yang akan dikumpulkan. Kemudian, sejumlah kendaraan pengangkut darah akan diberangkatan dari blood center menuju berbagai lokasi potensial yang terpilih untuk mengumpulkan darah hasil donasi dan membawanya kembali ke blood center untuk diproses lebih lanjut. Keterbatasan jumlah kendaraan pengangkut darah dapat menyebabkan tidak 
semua lokasi potensial dapat dikunjungi. Ilustrasi mengenai sistem jaringan pengumpulan darah yang akan dimodelkan dapat dilihat pada Gambar 1. Dalam model yang dibangun, blood center berperan sebagai depot dan lokasi donasi berperan sebagai supplier.

Dalam model yang dibangun, setiap kendaraan hanya dapat mengunjungi masingmasing supplier maksimal sekali. Masing-masing supplier hanya dapat dikunjungi oleh kendaraan pengangkut darah maksimal sekali. Darah memiliki spoilage time selama 6 jam dimulai sejak pick-up dilakukan.

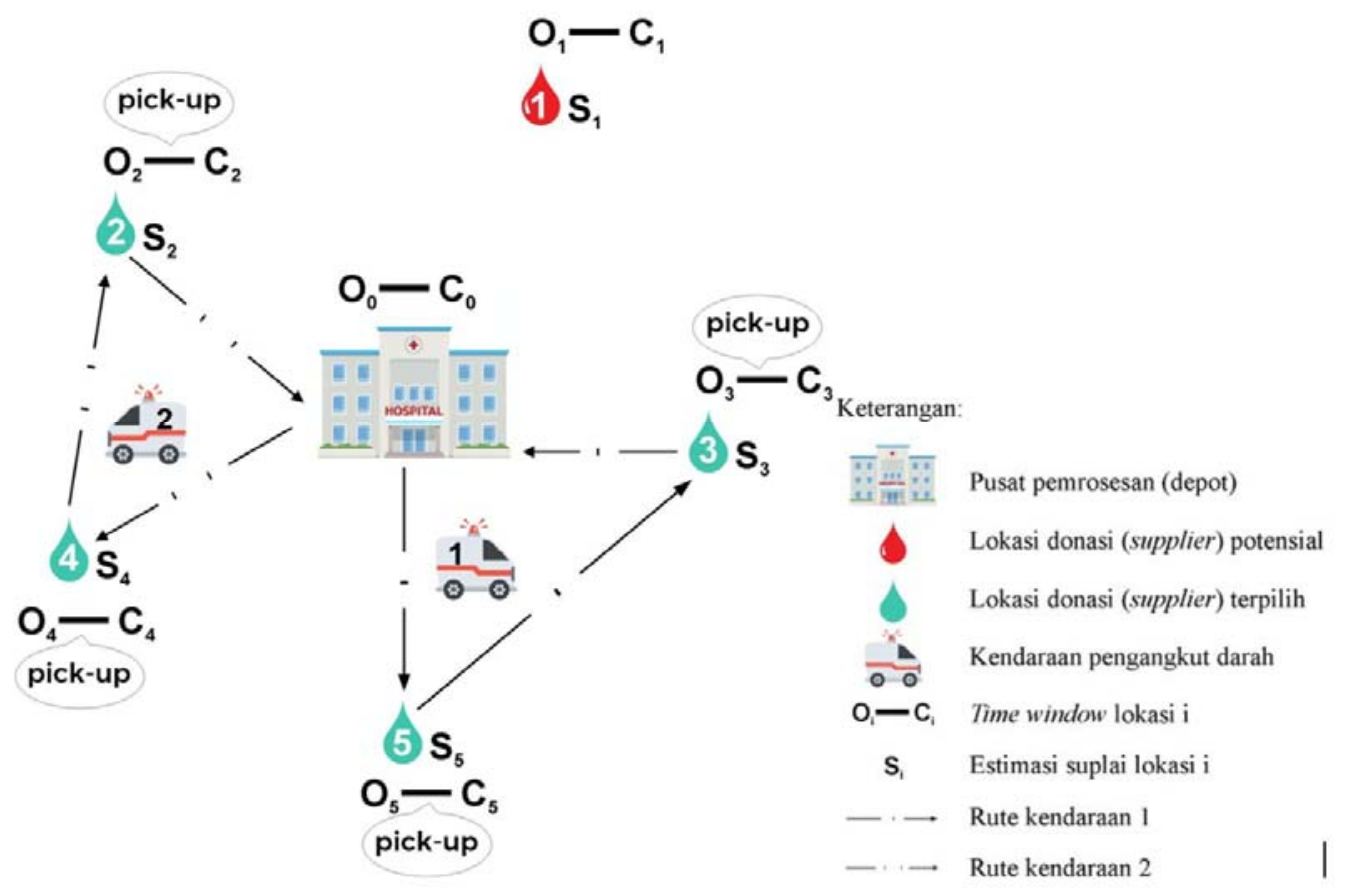

Gambar 1. Ilustrasi Sistem MBCRP

Model matematis yang dibuat memiliki beberapa set, indeks, parameter, dan variabel. Tabel 2 menunjukkan set dan indeks yang digunakan dalam model. Tabel 3 menunjukkan parameter yang terdapat dalam model. Tabel 4 menunjukkan variabel keputusan yang digunakan dalam model.

Tabel 2. Set dan indeks model matematis

\begin{tabular}{cl}
\hline Indeks & \multicolumn{1}{c}{ Definisi } \\
\hline $\boldsymbol{N}$ & Set titik depot dan supplier $(i, j, l=0, \ldots, N)$, dimana 0 merupakan indeks depot \\
$\boldsymbol{N}^{\prime}$ & Set titik supplier $(i, j=1, \ldots, N)$ \\
$\boldsymbol{K}$ & Set kendaraan $(k=1, \ldots, K)$ \\
\hline
\end{tabular}

Tabel 3. Parameter model matematis

\begin{tabular}{cl}
\hline Parameter & \multicolumn{1}{c}{ Definisi } \\
\hline $\boldsymbol{t}_{\boldsymbol{i j}}$ & Waktu tempuh dari titik $i$ ke $j$ \\
$\boldsymbol{o}_{\boldsymbol{i}}$ & Jam buka titik $i$ \\
$\boldsymbol{c}_{\boldsymbol{i}}$ & Jam tutup titik $i$ \\
$\boldsymbol{p}_{\boldsymbol{i}}$ & Suplai darah di titik $i$ \\
$\boldsymbol{\tau}$ & Spoilage time darah \\
$\boldsymbol{Q}$ & Kapasitas kendaraan \\
\hline
\end{tabular}


Tabel 4. Variabel model matematis

\begin{tabular}{cl}
\hline Variable & \multicolumn{1}{c}{ Definisi } \\
\hline $\boldsymbol{x}_{i j k}$ & $x_{i j k}=1$, jika kendaraan $k$ menempuh perjalanan dari titik $i$ ke $j ;$ \\
& $x_{i j k}=0$, lainnya \\
$\boldsymbol{a}_{\boldsymbol{i} \boldsymbol{k}}$ & Waktu keberangkatan kendaraan $k$ di titik $i$ \\
\hline
\end{tabular}

Model matematis dibuat dalam bentuk MINLP dengan notasi-notasi yang telah dijelaskan sebelumnya. Fungsi tujuan dan batasan model matematis yang telah dibuat yaitu sebagai berikut:

Fungsi tujuan:

$$
\text { maximize } \sum_{i \in N, i \neq j} \sum_{j \in N^{\prime}, j \neq i} \sum_{k \in K} p_{j} x_{i j k}
$$

Batasan:

$$
\begin{aligned}
& \sum_{i \in N} \sum_{k \in K} x_{i j k} \leq 1 \quad, \forall j \in N^{\prime}, i \neq j \\
& \sum_{j \in N^{\prime}} \sum_{k \in K} x_{0 j k} \leq K \\
& x_{i j k}+x_{j i k} \leq 1 \quad, \forall i \in N^{\prime}, j \in N^{\prime}, k \in K, i \neq j \\
& \sum_{i \in N, i \neq l} x_{i l k}=\sum_{j \in N, j \neq l} x_{l j k} \quad, \forall l \in N^{\prime}, k \in K \\
& o_{i}<a_{i k}<c_{i} \quad, \forall i \in N^{\prime}, k \in K \\
& a_{j k}=\sum_{i \in N, i \neq j}\left(a_{i k}+t_{i j}\right) x_{i j k} \quad, \forall j \in N^{\prime}, k \in K \\
& a_{0 k}+\sum_{i \in N, i \neq j} \sum_{j \in N, i \neq j} x_{i j k} t_{i j} \leq c_{0} \quad, \forall k \in K \\
& \sum_{i \in N, i \neq j} \sum_{j \in N, i \neq j} x_{i j k} t_{i j}-\sum_{j \in N^{\prime}} x_{0 j k} t_{0 j} \leq \tau \quad, \forall k \in K \\
& \sum_{i \in N, i \neq j} \sum_{j \in N^{\prime}, i \neq j} p_{i} x_{i j k} \leq Q \quad, \forall k \in K \\
& x_{i j k}=\{0,1\} \\
& a_{i k} \geq 0
\end{aligned}
$$


Penelitian ini memiliki fungsi tujuan untuk memaksimalkan jumlah darah yang dapat dikumpulkan oleh seluruh kendaraan pengangkut darah yang ditunjukkan pada persamaan (1). Batasan (2) menjelaskan bahwa setiap titik supplier hanya dapat dikunjungi sekali. Batasan (3) digunakan untuk memastikan bahwa jumlah kendaraan yang digunakan tidak melebihi jumlah kendaraan yang ada. Batasan (4) berfungsi untuk membatasi agar kendaraan tidak melewati jalur yang sama lebih dari sekali. Batasan (5) digunakan untuk memastikan jika suatu titik dikunjungi maka harus ditinggalkan. Batasan (6) mengatur agar jam keberangkatan kendaraan dari suatu titik selalu berada di dalam time-window titik tersebut. Batasan (7) memastikan jika suatu kendaraan melakukan perjalanan dari titik $i$ ke $j$ maka jam keberangkatan di titik $j$ sama dengan jam keberangkatan di titik $i$ ditambah waktu perjalanan dari $i$ ke $j$. Batasan (8) memastikan agar keberangkatan di depot ditambah dengan total waktu perjalanan yang dilakukan tidak melebihi jam tutup depot. Batasan (9) mengatur agar total waktu perjalanan yang dilalui oleh suplai darah yang diangkut menuju depot tidak melebihi spoilage time darah. Batasan (10) memastikan seluruh suplai darah yang diangkut tidak melebihi kapasitas kendaraan. Batasan (11) mendefinisikan bahwa variable keputusan $x_{i j k}$ merupakan variable biner. Keputusan $a_{i j k}$ bernilai non-negatif ditunjukkan pada batasan (12).

\subsection{Verifikasi dan Validasi Model Matematis}

Model matematika yang dibangun diverifikasi untuk memastikan bahwa model berjalan sesuai dengan logika yang diharapkan, yaitu sesuai dengan behaviour dari sistem. Proses verifikasi dilakukan dengan menggunakan software AMPL dengan CPLEX solver. Dalam menjalankan proses verifikasi, dibangkitkan kasus VRP sederhana dengan menggunakan 1 titik depot, 5 titik supplier, dan 2 unit kendaraan. Nilai parameter yang digunakan dapat dilihat pada Tabel 5-7.

Tabel 5. Nilai Parameter Waktu Tempuh $\left(t_{i j}\right)$

\begin{tabular}{|c|c|c|c|c|c|c|}
\hline Titik (i/j) & 0 & 1 & 2 & 3 & 4 & 5 \\
\hline 0 & 0 & 13,89 & 21,02 & 32,56 & 17,20 & 14,14 \\
\hline 1 & 13,89 & 0 & 12,37 & 19,21 & 31,06 & 22,20 \\
\hline 2 & 21,02 & 12,37 & 0 & 15,30 & 37,01 & 21,02 \\
\hline 3 & 32,56 & 19,21 & 15,30 & 0 & 49,68 & 36,06 \\
\hline 4 & 17,20 & 31,06 & 37,01 & 49,68 & 0 & 20,40 \\
\hline 5 & 14,14 & 22,20 & 21,02 & 36,06 & 20,40 & 0 \\
\hline
\end{tabular}

Tabel 6. Nilai Parameter Suplai $\left(p_{i}\right)$, Jam Buka $\left(o_{i}\right)$, dan Jam Tutup $\left(c_{i}\right)$

\begin{tabular}{|c|c|c|c|}
\hline $\begin{array}{c}\text { Titik } \\
(\boldsymbol{i})\end{array}$ & $\begin{array}{c}\text { Suplai Darah } \\
\left(\boldsymbol{p}_{\boldsymbol{i}}\right)\end{array}$ & $\begin{array}{c}\text { Jam Buka } \\
\left(\boldsymbol{o}_{\boldsymbol{i}}\right)\end{array}$ & $\begin{array}{c}\text { Jam Tutup } \\
\left(\boldsymbol{c}_{\boldsymbol{i}}\right)\end{array}$ \\
\hline 0 & - & 0 & 480 \\
\hline 1 & 7,2 & 60 & 180 \\
\hline 2 & 30,24 & 60 & 180 \\
\hline 3 & 16,32 & 60 & 180 \\
\hline 4 & 9,12 & 60 & 180 \\
\hline 5 & 21,12 & 60 & 180 \\
\hline
\end{tabular}


Tabel 7. Nilai Parameter Kapasitas $(Q)$ dan Spoilage Time $(\tau)$

\begin{tabular}{|l|c|}
\hline \multicolumn{1}{|c|}{ Parameter } & Nilai \\
\hline Kapasitas Kendaraan $(Q)$ & 40 \\
\hline Spoilage Time $(\tau)$ & 360 \\
\hline
\end{tabular}

Kasus yang dibuat kemudian diselesaikan dengan menggunakan model matematika dalam program komputer $A M P L$ dan diselesaikan dengan menggunakan $C P L E X$ solver. Hasil dari perhitungan dapat dilihat pada Tabel 8. Hasil perhitungan pada kasus sederhana dengan menggunakan CPLEX solver memberikan hasil optimum supply sebesar 76.8 dengan keputusan pengambilan rute 0-5-3-0 untuk kendaraan pertama dan rute 0-4-2-0. Supplier 1 tidak dikunjungi dikarenakan batasan kapasitas kendaraan. Model matematis yang dibangun pada software AMPL sudah dapat berjalan dengan tidak adanya error dan menghasilkan nilainilai variabel keputusan yang tidak menyalahi batasan-batasan, sehingga dapat dikatakan model matematis tersebut telah lulus uji verifikasi.

Tabel 8. Hasil perhitungan kasus sederhana

\begin{tabular}{c|c|c}
\hline \multicolumn{2}{l}{ Total supply $=\mathbf{7 6 . 8}$} \\
\hline \multicolumn{3}{c}{$\boldsymbol{x}_{\boldsymbol{i j k} \boldsymbol{k}}$} \\
\hline \multicolumn{3}{c}{$\boldsymbol{a}_{\boldsymbol{i k}}$} \\
\hline \multicolumn{3}{c}{ Rasil variabel keputusan } \\
\multicolumn{3}{c}{ Rute kendaraan 1: $0-5-3-0$} \\
\hline \multicolumn{3}{c}{ Kendaraan 2: $0-4-2-0$} \\
\hline $\mathbf{0}$ & 27.44 & 42.80 \\
\hline $\mathbf{1}$ & 0 & 0 \\
\hline $\mathbf{2}$ & 0 & 97.01 \\
\hline $\mathbf{3}$ & 60 & 0 \\
\hline $\mathbf{4}$ & 0 & 60 \\
\hline $\mathbf{5}$ & 96.06 & 0 \\
\hline
\end{tabular}

Setelah lulus uji verifikasi, model matematis kemudian diuji validasi. Uji validasi dilakukan dengan cara membandingkan hasil perhitungan yang didapatkan menggunakan software $A M P L$, dengan hasil perhitungan manual menggunakan metode enumerasi lengkap. Menurut Walukiewicz [17], jika suatu feasible solution pada suatu integer programming $P$ dibatasi, maka $F(P)$ mengandung jumlah feasible point yang finite, dan problem dapat diselesaikan dengan metode enumerasi lengkap. Akan tetapi, jika terdapat terlalu banyak kombinasi nilai variabel, maka perhitungan dengan metode enumerasi lengkap tidak terlalu membantu. Oleh karena itu, perhitungan enumerasi lengkap dilakukan dengan menggunakan kasus sederhana yang digunakan pada uji verifikasi.

Proses perhitungan manual dengan metode enumerasi lengkap dilakukan dengan cara membangkitkan seluruh kemungkinan kombinasi nilai variabel keputusan biner $x_{i j k}$. Kemungkinan tersebut kemudian dieliminasi menggunakan batasan-batasan yang ada. Setelah tidak ada lagi kombinasi nilai variabel keputusan yang melanggar batasan, hasil untuk masing-masing kombinasi dihitung secara manual dan dipilih hasil yang paling optimal di antara seluruh feasible solution yang dihasilkan. Dalam penelitian ini, total feasible solution yang tidak melanggar batasan flow, time-window, spoilage time, dan kapasitas 
kendaraan sebanyak 236 feasible solution. Rute optimal dari hasil enumerasi lengkap dapat dilihat pada Tabel 9.

Dari 236 feasible solution yang dibangkitkan, terdapat 8 rute yang memberikan hasil optimal, hal tersebut dapat terjadi karena data waktu tempuh bersifat simetris yang berarti waktu tempuh dari titik $i$ menuju $j$ akan sama dengan waktu tempuh dari titik $j$ menuju $i$. Sehingga yang membedakan hanyalah kombinasi urutan titik dan kendaraan. Dari 8 rute optimal pada enumerasi lengkap, terdapat satu rute yang sama dengan hasil yang didapatkan dari perhitungan pada software AMPL dengan total supply sebesar 76.8, yaitu rute pada nomor 153. Dengan hasil yang identik tersebut, maka dapat dikatakan model yang telah dibuat telah lulus rangkaian uji validasi hasil yang dilakukan.

Tabel 11. Total biaya tiap kemungkinan rute yang terjadi

\begin{tabular}{|c|c|c|c|}
\hline No. urut feasible solution & Rute kendaraan 1 & Rute kendaraan 2 & Total supply \\
\hline 100 & $0-2-4-0$ & $0-3-5-0$ & 76.8 \\
\hline 102 & $0-2-4-0$ & $0-5-3-0$ & 76.8 \\
\hline 117 & $0-3-5-0$ & $0-2-4-0$ & 76.8 \\
\hline 119 & $0-3-5-0$ & $0-4-2-0$ & 76.8 \\
\hline 129 & $0-4-2-0$ & $0-3-5-0$ & 76.8 \\
\hline 131 & $0-4-2-0$ & $0-5-3-0$ & 76.8 \\
\hline 151 & $0-5-3-0$ & $0-2-4-0$ & 76.8 \\
\hline 153 & $0-5-3-0$ & $0-4-2-0$ & 76.8 \\
\hline
\end{tabular}

\section{Kesimpulan}

Model matematis untuk memaksimalkan pengumpulan darah (maximum blood collection routing problem) telah berhasil dikembangkan. Model matematis yang dibuat telah lulus uji verifikasi dan validasi. Model tersebut dapat digunakan untuk menyelesaikan permasalahan penentuan lokasi event donor darah serta rute optimalnya. Model yang dikembangkan dapat digunakan untuk menyelesaikan permasalahan yang bersifat deterministik. Penelitian selanjutnya dapat diarahkan pada penggunaan metode metaheuristic agar pemasalahan yang diselesaikan dapat lebih besar.

\section{Ucapan Terimakasih}

Penulis ingin menyampaikan terimakasih dan penghargaan yang sebesar-besarnya kepada pihak Departemen Teknik Mesin dan Industri (DTMI), Fakultas Teknik (FT), Universitas Gadjah Mada (UGM) atas bantuan dana untuk penelitian ini dalam skema Hibah DTMI 2019 dengan SK No. 718/H1.17/TMI/LK/2019.

\section{Daftar Pustaka}

[1] Sherwood, L. (2011). Fundamentals of human physiology. Cengage Learning.

[2] Ekici, A., Özener, O. Ö., \& Çoban, E. (2018). Blood supply chain management and future research opportunities. In Operations Research Applications in Health Care Management (pp. 241-266). Springer, Cham.

[3] Davey, R. J. (2004). Recruiting blood donors: challenges and opportunities. Transfusion, 44(4), 597-600.

[4] Pusdatin Kemenkes RI, 2014, Situasi Donor Darah di Indonesia, online: http://www.depkes.go.id/download.php?file=download/pusdatin/infodatin/infodatindonor-darah.pdf, diakses 16 September 2017 
[5] Pusat Data dan Informasi Kementerian Kesehatan RI, 2017, Pelayanan Darah di Indonesia, Kementerian Kesehatan Republik Indonesia, Jakarta.

[6] Beliën, J., \& Forcé, H. (2012). Supply chain management of blood products: A literature review. European Journal of Operational Research, 217(1), 1-16.

[7] Kementerian Kesehatan Republik Indonesia, 2017, Program Kerja Sama antara Puskesmas, Unit Transfusi Darah, Rumah Sakit dalam Pelayanan Darah untuk Menurunkan Angka Kematian Ibu, online: http://yankes.kemkes.go.id/read-programkerja-sama-antara-puskesmas-unit-transfusi-darah-rumah-sakit-dalam-pelayanandarah-untuk-menurunkan-angka-kematian-ibu-1480.html, diakses 16 September 2017

[8] ABC Newsletter, 2004, America's Blood Center, online: http://www.americasblood.org/press-room/abc-newsletter.aspx, diakses 16 September 2017

[9] Şahinyazan, F. G., Kara, B. Y., \& Taner, M. R. (2015). Selective vehicle routing for a mobile blood donation system. European Journal of Operational Research, 245(1), 22-34.

[10] American Red Cross, 2008, Sponsoring a Blood Drive, online: https://web.archive.org/web/20080526101723/http://www.givelife2.org/sponsor/, diakses 28 Mei 2018.

[11] Yi, J. (2003). Vehicle routing with time windows and time-dependent rewards: A problem from the American Red Cross. Manufacturing \& Service Operations Management, 5(1), 74-77.

[12] American Red Cross Biomedical Services, 2015, A leader in providing lifesaving blood and blood products to the nation, online: http://www.redcrossblood.org, diakses 20 September 2017.

[13] American Red Cross Blood Services, 2015, What Happens to Donated Blood, online: https://www.redcrossblood.org/donate-blood/blood-donation-process/what-happensto-donated-blood.html, diakses 20 September 2017.

[14] National Health Service Blood and Transplant, 2016, The journey of a blood donation, online: $\quad$ https://www.blood.co.uk/the-donation-process/after-yourdonation/the-journey-of-a-blood-donation, diakses 16 September 2017.

[15] ABC Radio Darwin, 2016, Follow the blood bag: How Australian Red Cross processes life-saving donations, online: http://www.abc.net.au/news/2016-0323/australian-red-cross-what-happens-to-blood-after-donation/7267878, diakses 16 September 2017.

[16] Finnish Red Cross Blood Service, 2017, Blood donation events, online: https://www.bloodservice.fi/blood-donation/donate-blood/blood-donation-events, diakses 16 Mei 2018.

[17] Walukiewicz, S. (1991). Integer Programming. PWN. 